\title{
Influence of Urea Molasses Mineral Blocks having Bentonite as Binder on Haemato-Biochemical and Serum Mineral Profile of Crossbred Calves
}

\author{
V. Sankar ${ }^{1}$, Putan Singh ${ }^{2}$, A.K. Verma ${ }^{1 *}$, Ashok Kumar Patil ${ }^{3}$ and Dinesh Kumar ${ }^{4}$ \\ ${ }^{1}$ Mechari Sheep Research Station, Pottaneri, INDIA \\ ${ }^{2}$ Division of Animal Nutrition, ICAR-I.V.R.I., Izatnagar, (U.P.), INDIA \\ ${ }^{3}$ Department of Animal Nutrition, COVSc E AH, Mhow(M.P.), INDIA \\ ${ }^{4}$ College of Agriculture, JNKVV, Tikamgarh, (M.P.), INDIA \\ "Corresponding author: AK Verma; E-mail:vermaak62@gmail.com
}

Received: 16 June, 2020

Revised: 20 June, 2020

Accepted: 29 June, 2020

\begin{abstract}
The present experiment was conducted to study the effect of supplement of UMMB containing variable levels of urea and bentonite on haemato-biochemical and serum mineral profile of crossbred calves. Twenty four male crossbred calves were divided into four equal groups following complete randomized design and fed individually for 120 days. In group $\mathrm{T}_{1}, 70 \%$ of $\mathrm{CP}$ requirement was met through feeding of concentrate mixture and remaining $\mathrm{CP}$ was fed through urea molasses mineral block (UMMB) and ad libitum wheat straw (control). In group $\mathrm{T}_{2}, \mathrm{~T}_{3}$ and $\mathrm{T}_{4}$, the feeding regimen followed was same as that of control except that UMMB was replaced with UMMB-A, UMMB-B, UMMB-C which vary in physical. Blood samples were collected at $0,60,120$ day of experimental feeding to determine haemato-biochemical and serum mineral concentration. The mean values for $\mathrm{Hb}(\mathrm{mg} / \mathrm{dl})$, PCV $(\%)$, glucose $(\mathrm{mg} / \mathrm{dl})$, total protein $(\mathrm{g} / \mathrm{dl})$, albumin, globulin $(\mathrm{g} / \mathrm{dl}), \mathrm{A}: \mathrm{G}$ ratio, urea $(\mathrm{mg} / \mathrm{dl})$, creatinine, SGOT (IU/L), SGPT (IU/L) level was comparable ( $>0.05)$ among the different dietary treatments. the serum minerals $(\mathrm{Ca}$, $\mathrm{P}, \mathrm{Cu}, \mathrm{Fe}, \mathrm{Zn})$ concentration was also statically similar among the different groups. However, periodical significantly $(\mathrm{P}<0.05)$ higher values were observed for $\mathrm{Hb}(\mathrm{mg} / \mathrm{dl}), \mathrm{PCV}(\%)$, glucose (mg/dl), total protein (g/dl), albumin, globulin(g/dl), A:G ratio, urea $(\mathrm{mg} / \mathrm{dl})$, creatinine, $\mathrm{Ca}$ and $\mathrm{P}$ at 60 and 120 days of post feeding but it was comparable and lies in the normal physiological range. It was concluded that haemato-biochemical parameters of cross bred calves were not influenced by supplementation of urea molasses mineral blocks.
\end{abstract}

\section{HIGHLIGHTS}

(0) All the haemato-biochemical parameters were within the normal physiological range.

(0 Feeding of urea molasses mineral blocks had not any harmful effect on health of calves.

Keywords: Solid multi-nutrient blocks, Crossbred calves, Haemato-biochemical profile

In India livestock mainly subsist on poor quality feeds and fodder that are deficient in energy, protein, mineral and vitamin. As a result, performance of animal is often sub-optimal that is reflected in stunted growth, delayed maturity, longer inter-calving period and poor milk yield. Mineral deficiency in grazing ruminants has been reported by several authors (Bhandari et al., 2016) and supplementation is one way of tackling this problem. Dietary supplementation of critical nutrients can improve the utilization of poor quality roughages. Ruminants have the unique ability to convert NPN compounds in their diet to a microbial protein of high biological value. Keeping this fact in mind urea containing blocks known as urea molasses mineral block (UMMB) were developed to supplement the diet of ruminants fed on poor quality

How to cite this article: Sankar, V., Singh, P., Verma, A.K., Patil, A.K. and Kumar, D. (2020). Influence of urea molasses mineral blocks having bentonite as binder on haemato-biochemical and serum mineral profile of crossbred calves. J. Anim. Res., 10(4): 651-658.

Source of Support: None; Conflict of Interest: None 
roughages (Kumari et al., 2020, Patil et al., 2019 and Ankita et al., 2016, Anuraj et al., 2017). Supplementation of urea molasses mineral block (UMMB) can show promising results in improving the nutrient utilization and also the productivity of animals (Prasad et al., 2001). If the block is too soft, it will be licked out rapidly and if it is too hard it may not be consumed at all (Kunju, 1986). A binder is necessary in order to solidify the blocks, in that bentonite have many advantages than that of other binders. Bentonite is one of the common natural clays used in animal diets to improve digestibility of nutrients and daily gain and feed intake (Salem et al., 2001). There are numerous animal feeding studies, which demonstrated that bentonites, can bind toxins (aflatoxins) in ingested feed and reduce or eliminate the toxicity (Dos Anjos et al., 2015). The addition of bentonite to the diet can partly equalize the supply of nitrogen to the rumen microorganisms. Information is also scanty in the literature regarding the combined effect of bentonite and cement as a binder in the urea molasses mineral block on performance of animals and keeping quality of the block. Keeping the above facts in view, this study was undertaken to see the influence of urea molasses mineral blocks having bentonite as binder on haemato-biochemical and serum mineral profile of crossbred calves.

\section{MATERIALS AND METHODS}

\section{Selection of animals, experimental design and dietary treatments}

Twenty four healthy crossbred calves were selected and housed in a separate shed of having provision of both open and close space at Animal Nutrition Shed, ICARIndian Veterinary Research Institute, Izatnagar. Prior to the experimental feeding, all animals were dewormed and vaccinated against various diseases. Proper health management and sanitation conditions were maintained throughout the experimental period. Twenty four crossbred growing calves of 9-12 month age were selected on the basis of age $(9-12 \mathrm{~m})$ and body weight $(134 \pm 1.0 \mathrm{~kg})$ and divided into four groups $(n=6)$ by using completely randomization design and fed as per Ranjhan (1998) to meet the maintenance and growth requirement. In group $\mathrm{T}_{1}, 70 \%$ of $\mathrm{CP}$ requirement was met through feeding of concentrate mixture and remaining $\mathrm{CP}$ was fed through urea molasses mineral block (UMMB) and ad libitum wheat straw (control). In group $\mathrm{T}_{2}, \mathrm{~T}_{3}$ and $\mathrm{T}_{4}$, the feeding regimen followed was same as that of control except that UMMB was replaced with UMMB-A, UMMB-B, UMMB-C which vary in physical composition (wheat bran, urea, cement and bentonite content). The concentrate mixture for animals consisted of crushed maize, 43; wheat bran, 42; deoiled soy bean, 12; mineral mixture, 02 and common salt, $01 \%$ for feeding of animals throughout experimental period. The experiment was conducted for 120 days. Blood was collected at 0,60 and 120 days of experimental trial by jugular vein puncture and serum was collected and then stored at $-20^{\circ} \mathrm{C}$ until further analysis. Serum was analysed after thawing for various biochemical and enzymatic profile by standard protocol using commercial diagnostic kit.

\section{STATISTICAL ANALYSIS}

The experimental data generated were analyzed using statistical package SPSS 11.0 adopting standard statistical procedures (Snedecor and Cochran, 1994). Significance was declared at $\mathrm{p}<0.05$ unless otherwise stated.

\section{RESULTS AND DISCUSSION}

The result of hematological and biochemical blood parameters in cross bred calves has been presented in Table 1 and 2. The blood indices viz. haemoglobin, packed cell volume, glucose, total proteins, albumin, globulin and A : G ratio, serum urea, Creatinine, Serum calcium and phosphorus, serum copper iron, zinc and serum enzymes viz. ALT and AST were not affected by supplementation among the different groups, however, their periodical means varied significantly at different time intervals.

\section{Effect of feeding urea molasses mineral blocks on haematological parameter}

Blood haemoglobin $(\mathrm{Hb})$ is an indicator of erythrocytic normal level and general well beings of animals. The $\mathrm{Hb}$ values and PCV values varied from 11.38 to $11.60 \mathrm{~g} / \mathrm{dl}$ and 28.46 to 29.00 respectively, across different treatments and statically comparable. However, Significantly $(\mathrm{P}<0.05)$ higher changes in the concentration was noticed at $60 \mathrm{~d}$ and 120 days of post feeding but it was comparable and within the normal physiological range (Kaneko, 2008). 
Table 1: Haematological parameters in crossbred calves fed different types of urea molasses blocks

\begin{tabular}{|c|c|c|c|c|c|c|c|}
\hline \multirow{2}{*}{ Attributes } & \multicolumn{3}{|c|}{ Period } & Monon & \multicolumn{3}{|c|}{ P value } \\
\hline & 0 day & 60 day & 120 day & vean $\pm \mathrm{SE}$ & $\bar{G}$ & $\mathbf{P}$ & $G * P$ \\
\hline \multicolumn{8}{|c|}{ Hemoglobin (g/dl) } \\
\hline $\mathrm{T}_{1}$ & $10.9 \pm 0.21$ & $11.5 \pm 0.32$ & $11.7 \pm 0.32$ & $11.4 \pm 0.18$ & \multirow{5}{*}{0.78} & \multirow{5}{*}{0.01} & \multirow{5}{*}{0.99} \\
\hline $\mathrm{T}_{2}$ & $11.0 \pm 0.24$ & $11.7 \pm 0.34$ & $12.1 \pm 0.34$ & $11.6 \pm 0.20$ & & & \\
\hline $\mathrm{T}_{3}^{2}$ & $10.6 \pm 0.16$ & $11.6 \pm 0.20$ & $11.9 \pm 0.32$ & $11.5 \pm 0.17$ & & & \\
\hline $\mathrm{T}_{4}^{3}$ & $10.9 \pm 0.21$ & $11.7 \pm 0.31$ & $12.1 \pm 0.42$ & $11.6 \pm 0.21$ & & & \\
\hline Mean $\pm \mathrm{SE}^{* *}$ & $10.9^{\mathrm{A}} \pm 0.10$ & $11.6^{\mathrm{B}} \pm 0.14$ & $11.9^{\mathrm{B}} \pm 0.17$ & & & & \\
\hline \multicolumn{8}{|c|}{ Packed cell volume (\%) } \\
\hline $\mathrm{T}_{1}$ & $27.3 \pm 0.52$ & $28.7 \pm 0.81$ & $29.3 \pm 0.80$ & $28.5 \pm 0.44$ & & & \\
\hline $\mathrm{T}_{2}$ & $27.5 \pm 0.60$ & $29.3 \pm 0.86$ & $30.2 \pm 0.85$ & $29.0 \pm 0.50$ & & & \\
\hline $\mathrm{T}_{3}$ & $27.1 \pm 0.41$ & $28.9 \pm 0.49$ & $29.9 \pm 0.81$ & $28.7 \pm 0.43$ & 0.78 & 0.01 & 0.99 \\
\hline $\mathrm{T}_{4}$ & $27.3 \pm 0.52$ & $29.1 \pm 0.77$ & $30.4 \pm 1.04$ & $28.9 \pm 0.53$ & & & \\
\hline Mean $\pm \mathrm{SE}^{* *}$ & $27.5 \pm 0.60$ & $29.3 \pm 0.86$ & $30.2 \pm 0.85$ & $29.0 \pm 0.50$ & & & \\
\hline
\end{tabular}

A,B Mean values different superscripts with in a row differ significantly.

Table 2: Biochemical parameters in cross bred calves fed different types of urea molasses blocks

\begin{tabular}{|c|c|c|c|c|c|c|c|}
\hline \multirow{2}{*}{ Attributes } & \multicolumn{3}{|c|}{ Period } & \multirow{2}{*}{ - Mean \pm SE } & \multicolumn{3}{|c|}{ P value } \\
\hline & 0 day & 60 day & 120 day & & G & $\mathbf{P}$ & $\mathbf{G * P}$ \\
\hline \multicolumn{8}{|c|}{ Glucose (mg/dl) } \\
\hline $\mathrm{T}_{1}$ & $49.6 \pm 0.78$ & $52.6 \pm 1.19$ & $54.3 \pm 0.72$ & $52.7 \pm 0.65$ & \multirow{5}{*}{0.42} & \multirow{5}{*}{0.01} & \multirow{5}{*}{0.64} \\
\hline $\mathrm{T}_{2}$ & $50.2 \pm 1.33$ & $53.3 \pm 0.37$ & $55.4 \pm 0.79$ & $52.9 \pm 0.72$ & & & \\
\hline $\mathrm{T}_{3}$ & $48.0 \pm 0.74$ & $52.7 \pm 1.40$ & $54.2 \pm 1.28$ & $51.6 \pm 0.91$ & & & \\
\hline $\mathrm{T}_{4}$ & $49.3 \pm 0.53$ & $54.6 \pm 1.05$ & $53.5 \pm 1.19$ & $52.5 \pm 0.76$ & & & \\
\hline Mean $\pm \mathrm{SE}$ & $49.3^{\mathrm{A}} \pm 0.45$ & $53.3^{\mathrm{B}} \pm 0.53$ & $54.3^{\mathrm{B}} \pm 0.50$ & & & & \\
\hline \multicolumn{8}{|c|}{ Total Protein (g/dl) } \\
\hline $\mathrm{T}_{1}$ & $6.8 \pm 0.12$ & $6.9 \pm 0.09$ & $7.1 \pm 0.10$ & $6.9 \pm 0.06$ & \multirow{5}{*}{0.22} & \multirow{5}{*}{0.01} & \multirow{5}{*}{0.85} \\
\hline $\mathrm{T}_{2}$ & $6.8 \pm 0.14$ & $6.9 \pm 0.10$ & $7.2 \pm 0.08$ & $6.9 \pm 0.07$ & & & \\
\hline $\mathrm{T}_{3}$ & $7.0 \pm 0.09$ & $7.1 \pm 0.14$ & $7.3 \pm 0.08$ & $7.2 \pm 0.06$ & & & \\
\hline $\mathrm{T}_{4}$ & $7.0 \pm 0.11$ & $7.2 \pm 0.13$ & $7.1 \pm 0.14$ & $7.1 \pm 0.07$ & & & \\
\hline Mean $\pm \mathrm{SE}$ & $6.9^{\mathrm{A}} \pm 0.06$ & $7.1^{\mathrm{AB}} \pm 0.05$ & $7.2^{\mathrm{B}} \pm 0.05$ & & & & \\
\hline \multicolumn{8}{|c|}{ Albumin (g/dl) } \\
\hline $\mathrm{T}_{1}$ & $3.3 \pm 0.10$ & $3.4 \pm 0.05$ & $3.6 \pm 0.04$ & $3.4 \pm 0.05$ & \multirow{5}{*}{0.10} & \multirow{5}{*}{0.01} & \multirow{5}{*}{0.14} \\
\hline $\mathrm{T}_{2}$ & $3.4 \pm 0.11$ & $3.5 \pm 0.07$ & $3.7 \pm 0.04$ & $3.5 \pm 0.05$ & & & \\
\hline $\mathrm{T}_{3}$ & $3.3 \pm 0.06$ & $3.3 \pm 0.04$ & $3.5 \pm 0.04$ & $3.4 \pm 0.05$ & & & \\
\hline $\mathrm{T}_{4}$ & $3.4 \pm 0.07$ & $3.5 \pm 0.05$ & $3.5 \pm 0.05$ & $3.5 \pm 0.03$ & & & \\
\hline Mean $\pm \mathrm{SE}$ & $3.3^{\mathrm{A}} \pm 0.04$ & $3.4^{\mathrm{A}} \pm 0.03$ & $3.6^{\mathrm{B}} \pm 0.03$ & & & & \\
\hline \multicolumn{8}{|c|}{ Globulin (g/dl) } \\
\hline $\mathrm{T}_{1}$ & $3.5 \pm 0.16$ & $3.6 \pm 0.12$ & $3.5 \pm 0.13$ & $3.5 \pm 0.07$ & \multirow{5}{*}{0.51} & \multirow{5}{*}{0.49} & \multirow{5}{*}{0.2} \\
\hline $\mathrm{T}_{2}$ & $3.5 \pm 0.05$ & $3.4 \pm 0.11$ & $3.5 \pm 0.09$ & $3.5 \pm 0.05$ & & & \\
\hline $\mathrm{T}_{3}$ & $3.8 \pm 0.08$ & $3.3 \pm 0.20$ & $3.6 \pm 0.07$ & $3.6 \pm 0.09$ & & & \\
\hline $\mathrm{T}_{4}$ & $3.6 \pm 0.15$ & $3.7 \pm 0.13$ & $3.6 \pm 0.12$ & $3.6 \pm 0.07$ & & & \\
\hline Mean $\pm \mathrm{SE}$ & $3.6 \pm 0.06$ & $3.5 \pm 0.07$ & $3.6 \pm 0.07$ & & & & \\
\hline
\end{tabular}




\begin{tabular}{|c|c|c|c|c|c|c|c|}
\hline \multicolumn{8}{|c|}{ A/G ratio } \\
\hline $\mathrm{T}_{1}$ & $0.95 \pm 0.06$ & $0.97 \pm 0.04$ & $1.1 \pm 0.04$ & $0.99 \pm 0.03$ & \multirow{5}{*}{0.35} & \multirow{5}{*}{0.01} & \multirow{5}{*}{0.80} \\
\hline $\mathrm{T}_{2}$ & $0.98 \pm 0.03$ & $1.1 \pm 0.05$ & $1.1 \pm 0.02$ & $1.0 \pm 0.02$ & & & \\
\hline $\mathrm{T}_{3}$ & $0.88 \pm 0.02$ & $1.0 \pm 0.05$ & $1.0 \pm 0.02$ & $0.97 \pm 0.02$ & & & \\
\hline $\mathrm{T}_{4}$ & $0.93 \pm 0.06$ & $0.97 \pm 0.03$ & $0.98 \pm 0.02$ & $0.96 \pm 0.02$ & & & \\
\hline Mean \pm SE & $0.94^{\mathrm{A}} \pm 0.02$ & $0.99^{\mathrm{AB}} \pm 0.02$ & $1.0^{\mathrm{B}} \pm 0.02$ & & & & \\
\hline \multicolumn{8}{|c|}{ Urea $(\mathrm{mg} / \mathrm{dl})$} \\
\hline $\mathrm{T}_{1}$ & $17.5 \pm 2.30$ & $29.0 \pm 2.16$ & $29.7 \pm 1.83$ & $25.4 \pm 1.77$ & \multirow{5}{*}{0.97} & \multirow{5}{*}{0.01} & \multirow{5}{*}{0.42} \\
\hline $\mathrm{T}_{2}$ & $17.5 \pm 1.32$ & $29.0 \pm 4.51$ & $27.3 \pm 2.10$ & $24.6 \pm 2.03$ & & & \\
\hline $\mathrm{T}_{3}$ & $22.8 \pm 3.81$ & $24.6 \pm 3.87$ & $25.5 \pm 0.93$ & $24.3 \pm 1.75$ & & & \\
\hline $\mathrm{T}_{4}$ & $21.2 \pm 5.39$ & $23.2 \pm 3.24$ & $29.2 \pm 2.00$ & $24.5 \pm 2.23$ & & & \\
\hline Mean \pm SE & $19.7^{\mathrm{A}} \pm 1.73$ & $26.4^{\mathrm{B}} \pm 1.74$ & $27.9^{\mathrm{B}} \pm 0.90$ & & & & \\
\hline \multicolumn{8}{|c|}{ Creatinine (mg/dl) } \\
\hline $\mathrm{T}_{1}$ & $1.2 \pm 0.11$ & $1.3 \pm 0.07$ & $1.5 \pm 0.08$ & $1.3 \pm 0.05$ & \multirow{5}{*}{0.47} & \multirow{5}{*}{0.01} & \multirow{5}{*}{0.90} \\
\hline $\mathrm{T}_{2}$ & $1.0 \pm 0.15$ & $1.4 \pm 0.10$ & $1.5 \pm 0.09$ & $1.3 \pm 0.08$ & & & \\
\hline $\mathrm{T}_{3}^{2}$ & $1.3 \pm 0.21$ & $1.4 \pm 0.18$ & $1.7 \pm 0.06$ & $1.5 \pm 0.10$ & & & \\
\hline $\mathrm{T}_{4}^{3}$ & $1.3 \pm 0.19$ & $1.4 \pm 0.09$ & $1.5 \pm 0.12$ & $1.4 \pm 0.08$ & & & \\
\hline$\stackrel{4}{\text { Mean }} \pm$ SE & $1.2^{\mathrm{A}} \pm 0.08$ & $1.4^{\mathrm{AB}} \pm 0.06$ & $1.5^{\mathrm{B}} \pm 0.05$ & & & & \\
\hline \multicolumn{8}{|c|}{ Calcium (mg/dl) } \\
\hline $\mathrm{T}_{1}$ & $8.6 \pm 0.26$ & $9.6 \pm 0.09$ & $10.2 \pm 0.13$ & $9.5 \pm 0.19$ & \multirow{5}{*}{0.36} & \multirow{5}{*}{0.01} & \multirow{5}{*}{0.99} \\
\hline $\mathrm{T}_{2}$ & $8.5 \pm 0.14$ & $9.4 \pm 0.09$ & $10.1 \pm 0.33$ & $9.3 \pm 0.20$ & & & \\
\hline $\mathrm{T}_{3}^{2}$ & $8.4 \pm 0.14$ & $9.3 \pm 0.11$ & $9.9 \pm 0.23$ & $9.2 \pm 0.18$ & & & \\
\hline $\mathrm{T}_{4}^{3}$ & $8.4 \pm 0.10$ & $9.3 \pm 0.14$ & $10.0 \pm 0.15$ & $9.3 \pm 0.18$ & & & \\
\hline$\stackrel{4}{\text { Mean }} \pm$ SE & $8.5^{\mathrm{A}} \pm 0.08$ & $9.4^{\mathrm{B}} \pm 0.06$ & $10.1^{\mathrm{C}} \pm 0.11$ & & & & \\
\hline \multicolumn{8}{|c|}{ Phosphorus (mg/dl) } \\
\hline $\mathrm{T}_{1}$ & $4.9 \pm 0.26$ & $5.4 \pm 0.18$ & $5.9 \pm 0.12$ & $5.4 \pm 0.14$ & \multirow{5}{*}{0.69} & \multirow{5}{*}{0.01} & \multirow{5}{*}{0.92} \\
\hline $\mathrm{T}_{2}$ & $4.9 \pm 0.32$ & $5.5 \pm 0.08$ & $5.9 \pm 0.07$ & $5.5 \pm 0.14$ & & & \\
\hline $\mathrm{T}_{3}^{2}$ & $5.1 \pm 0.23$ & $5.3 \pm 0.17$ & $5.7 \pm 0.18$ & $5.4 \pm 0.12$ & & & \\
\hline $\mathrm{T}_{4}$ & $4.8 \pm 0.11$ & $5.5 \pm 0.13$ & $5.7 \pm 0.11$ & $5.4 \pm 0.11$ & & & \\
\hline Mean \pm SE & $4.9^{\mathrm{A}} \pm 0.12$ & $5.4^{\mathrm{B}} \pm 0.07$ & $5.8^{\mathrm{C}} \pm 0.06$ & & & & \\
\hline \multicolumn{8}{|c|}{ Aspartate Transferase AST (IU/L) } \\
\hline $\mathrm{T}_{1}$ & $79.2 \pm 7.03$ & $86.7 \pm 5.71$ & $87.5 \pm 5.30$ & $84.5 \pm 3.41$ & \multirow{5}{*}{0.86} & \multirow{5}{*}{0.35} & \multirow{5}{*}{0.99} \\
\hline $\mathrm{T}_{2}$ & $81.7 \pm 4.36$ & $87.1 \pm 1.89$ & $88.9 \pm 1.84$ & $85.9 \pm 1.76$ & & & \\
\hline $\mathrm{T}_{3}$ & $82.4 \pm 0.78$ & $86.0 \pm 2.26$ & $89.2 \pm 2.62$ & $85.9 \pm 1.30$ & & & \\
\hline $\mathrm{T}_{4}$ & $81.1 \pm 2.56$ & $87.7 \pm 3.66$ & $89.1 \pm 8.85$ & $85.9 \pm 3.22$ & & & \\
\hline Mean \pm SE & $81.1 \pm 2.04$ & $86.9 \pm 1.73$ & $88.7 \pm 2.52$ & & & & \\
\hline & & & ne Transferas & (IU/L) & & & \\
\hline $\mathrm{T}_{1}$ & & $22.6 \pm 1.56$ & $23.9 \pm 0.95$ & $22.9 \pm 0.84$ & & & \\
\hline $\mathrm{T}_{2}$ & & $24.0 \pm 1.06$ & $25.0 \pm 3.30$ & $24.0 \pm 1.22$ & & & \\
\hline $\mathrm{T}_{3}$ & & $23.8 \pm 1.61$ & $26.7 \pm 3.01$ & $24.7 \pm 1.16$ & 0.97 & 0.06 & 1.00 \\
\hline $\mathrm{T}_{4}$ & & $22.9 \pm 1.10$ & $24.6 \pm 1.37$ & $23.9 \pm 0.75$ & & & \\
\hline$\stackrel{4}{4}^{2} \mathrm{SE}$ & & $25.0 \pm 1.13$ & $23.9 \pm 0.50$ & & & & \\
\hline
\end{tabular}

The result was in correlation with Patil et al. (2017) on feeding molasses based multinutrients and chromium supplementation in lactating Murrah buffaloes. The present results suggested that UMMB feeding of calves induced no adverse effect on target haematological parameters and general health remained satisfactory in calves throughout the experiment period.
Effect of feeding urea molasses mineral blocks on biochemical parameters

\section{Serum glucose}

The glucose level is an indicator of the normal physiological conditions and well being of animals. The mean values for serum glucose of all the experimental calves varied from 
51.61 to $52.94 \mathrm{mg} / \mathrm{dl}$. In present results, no any significant effect of supplementation of urea molasses mineral blocks on serum glucose was observed among the various groups. Our results are in agreement with the findings of Sihag et al. (2008) who observed that there was no significant effect in the blood glucose levels of UMMB supplemented groups in buffaloes. However, Significantly $(\mathrm{P}<0.05)$ higher changes in the glucose concentration could be noticed at $60 \mathrm{~d}$ and 120 days of post feeding and these results was well corroborated of results of Tiwari (1988) and Jain et al. (2005) they reported that supplementation of readily available carbohydrates with NPN to the basal diet increased the level of blood glucose and rumen propionic acid. Contrary results were also reported by Kumar et al. (2016) and Kerketta et al. (2019).

\section{Serum proteins}

The serum protein level is an indicative of the balance between anabolism and catabolism of protein in the body. Total protein concentration in healthy animals normally varies between 6.0 and $7.9 \mathrm{~g} / \mathrm{dl}$ and is altered during any liver and kidney diseases (Kaneko, 1980). In the present study, serum total proteins, albumin and A: $G$ ratio remained within normal range and did not differ significantly $(\mathrm{P}>0.05)$ among different dietary treatments. This indicates that experimental feeds had no deleterious effect on serum proteins, albumin and A: G ratio. Contrary to our findings, Haili et al. (2014) who reported significant increase in total serum protein level in fattening cattle who received ad lib UMMB supplementation. Singh et al. (2010) also reported significant increase in total plasma protein and albumin level in buffaloes fed with urea molasses multi nutrient blocks enriched with area specific mineral mixture. Similar trend was also noticed by Raman et al. (2010) in buffaloes and marginally higher plasma protein concentrations may indicate greater availability of amino acids in UMMB fed calves.

\section{Serum urea}

The mean serum urea varied from 24.31 to $25.37 \mathrm{mg} / \mathrm{dl}$ across different treatments and was statically $(\mathrm{P}>0.05)$ similar among the various groups. In the present experiment, BUN values were within the normal physiological range indicating that urea molasses supplementation had not any harmful effect on liver and general health of cross bred calves. Similar results were obtained by Raman et al. (2010) and this may be attributed to low consumption of UMMB and slow release of NH3. However, contrary results were obtained by Mohini and Gupta (1993); Choubey et al. (2015) and Wadhwa and Bakshi (2014).

\section{Serum creatinine}

Serum creatinine levels can change when animals are either in a stress condition or generating insufficient dietary energy to maintain a normal physiological condition (Lehninger et al., 1993). There was no significant difference among the groups, but significant difference was observed at different period intervals. However, the mean values of serum Creatinine found in present experiment were within the normal range of 1.0 to $2.7 \mathrm{mg} \%$, as reported for the domestic animals (Kaneko, 1988). In our study in agreement with Jain et al. (2005) who observed non significant changes in plasma creatinine levels in UMMB feeding as compared to control in goats. Similar trends were reported by Tiwari (1988) in buffaloes calves supplemented with UMMB.

\section{Serum calcium and phosphorus}

Serum calcium levels were normal among the 4 groups receiving blocks. There was no significant difference among the 4 groups, but significant difference was observed in period mean at different intervals (60 and 120 days). Parallel to serum calcium, serum phosphorus was also significantly different at different time intervals. This is due to UMMB containing high amount of calcium and phosphorus which might have resulted in higher serum calcium and phosphorus levels in all 4 groups. The findings were in accordance with Haili et al. (2014), who observed significant increase in calcium and phosphorus level in fattening cattle fed with ad libitum UMMB for an experimental period of 90 days. This indicated that animals in all 4 groups were getting adequate dietary calcium and phosphorus for depositing in bone tissue and also maintaining normal calcium level.

\section{Serum AST and ALT}

There was no variation in the activity of AST and ALT among the treatments across various time intervals in treatments T1, T2, T3 and T4, respectively, which was in 
Sa

Sankar et al.

Table 3: Serum micro minerals in crossbred calves fed different types of urea molasses blocks

\begin{tabular}{|c|c|c|c|c|c|c|}
\hline \multirow[t]{2}{*}{ Attributes } & \multicolumn{2}{|c|}{ Periods } & \multicolumn{4}{|c|}{ P value } \\
\hline & 60 day & 120 day & Mean $\pm \mathbf{S E}$ & G & $\mathbf{P}$ & $G * P$ \\
\hline \multicolumn{7}{|c|}{ Copper (ppm) } \\
\hline $\mathrm{T}_{1}$ & $0.56 \pm 0.04$ & $0.61 \pm 0.03$ & $0.58 \pm 0.03$ & & & \\
\hline $\mathrm{T}_{2}$ & $0.51 \pm 0.08$ & $0.68 \pm 0.05$ & $0.59 \pm 0.05$ & & & \\
\hline $\mathrm{T}_{3}$ & $0.54 \pm 0.03$ & $0.64 \pm 0.04$ & $0.59 \pm 0.03$ & 0.49 & 0.07 & 0.34 \\
\hline $\mathrm{T}_{4}$ & $0.63 \pm 0.02$ & $0.66 \pm 0.02$ & $0.64 \pm 0.02$ & & & \\
\hline Mean $\pm \mathrm{SE}$ & $0.56 \pm 0.02$ & $0.64 \pm 0.02$ & & & & \\
\hline \multicolumn{7}{|c|}{ Iron (ppm) } \\
\hline $\mathrm{T}_{1}$ & $0.74 \pm 0.12$ & $0.98 \pm 0.23$ & $0.86 \pm 0.13$ & & & \\
\hline $\mathrm{T}_{2}$ & $0.84 \pm 0.17$ & $1.4 \pm 0.14$ & $1.1 \pm 0.14$ & & & \\
\hline $\mathrm{T}_{3}$ & $0.93 \pm 0.35$ & $1.4 \pm 0.06$ & $1.2 \pm 0.18$ & 0.34 & 0.18 & 0.81 \\
\hline $\mathrm{T}_{4}$ & $0.76 \pm 0.29$ & $0.97 \pm 0.10$ & $0.87 \pm 0.15$ & & & \\
\hline Mean $\pm \mathrm{SE}$ & $0.82 \pm 0.12$ & $1.2 \pm 0.08$ & & & & \\
\hline \multicolumn{7}{|c|}{ Zinc (ppm) } \\
\hline $\mathrm{T}_{1}$ & $0.86 \pm 0.07$ & $1.1 \pm 0.59$ & $0.96 \pm 0.28$ & & & \\
\hline $\mathrm{T}_{2}$ & $0.95 \pm 0.11$ & $1.2 \pm 0.49$ & $1.1 \pm 0.24$ & & & \\
\hline $\mathrm{T}_{3}$ & $0.95 \pm 0.15$ & $1.2 \pm 0.60$ & $1.0 \pm 0.29$ & 0.77 & 0.44 & 0.99 \\
\hline $\mathrm{T}_{4}$ & $0.71 \pm 0.06$ & $0.79 \pm 0.17$ & $0.75 \pm 0.09$ & & & \\
\hline Mean $\pm \mathrm{SE}$ & $0.87 \pm 0.05$ & $1.06 \pm 0.23$ & & & & \\
\hline
\end{tabular}

corroboration with Cenesiz et al. (2006) who reported no effect of urea molasses supplementation on the activity of SGPT and SGOT in lambs. However, Kerketta et al. (2019) reported that SGOT and SGPT values increased significantly by using urea molasses mineral block supplement, Tiwari et al. (2010) also found similar observation in goat kids. The activity of SGOT and SGPT is an indicator of damage to liver and muscles (Silanikove et al., 1996; Casteel, 1999). In our experiment the level of SGPT and SGOT were comparable to that of the control group, depicting that supplementation of MMS and chromium has no harmful and degenerative effect on hepatic cells and muscle tissues.

\section{Serum copper, iron and zinc}

There was no significant difference among the 4 groups in serum copper, iron and zinc level (Table 3 ). Serum mineral profile was observed within the reported range (Phukan et al., 2000). This indicated that animals in all 4 groups were receiving adequate dietary minerals from the blocks.

\section{CONCLUSION}

From the results of the present findings, it may be concluded that the blood biochemical parameters were not influenced by supplementation of urea molasses mineral blocks and supplementation did not have any adverse effects on the health of cross bred calves.

\section{ACKNOWLEDGEMENTS}

The authors are thankful to the Director, ICAR- Indian Veterinary Research Institute, Izatnagar, Bareilly for providing necessary facilities to carry out this study.

\section{REFERENCES}

Ankita, Verma, A.K., Singh, P., Das, A. and Gaur, G.K. 2016. Effect of replacement of concentrate mixture with a multinutrient liquid supplement on performance of bufflao heifers. Indian J. Anim. Sci., 86 (9): 1036-1040.

Anuraj, K.S., Singh, P., Verma, A.K., Chaturvedi, V.B. and Gaur, G.K. 2017. Effect of feeding molasses based multi-nutrient liquid supplement on early lactation performance, intake and nutrient digestibility in crossbred cows. J. Exp. Biol. Agric. Sci., 5(4): 545-549.

Bhandari, B. M., Goswami, A., Garg, M.R. and Samanta, S. 2016. Study on minerals status of dairy cows and their supplementation through area specific mineral mixture in the state of Jharkhand. J. Anim. Sci. Technol., 58: 1-8.

Cenesiz, S., Atakisi, O., Ozcan, A., Yuceyurt, R. and Unal, Y. 2006. Effect of feed supplemented with urea molasses mineral 
block on the asctivity of serum AST, ALT and levels of total protein, glucose, trigyceride, total lipid and total cholesterol in lambs. Kafkas. Univ. Vet. Fak. Derg., 12(2): 137-140.

Dos Anjos, F.R., Ledoux, D.R., Rottinghaus, G.E. and Chimonyo, M. 2015. Efficacy of adsorbents (bentonite and diatomaceous earth) and turmeric (Curcuma longa) in alleviating the toxic effects of aflatoxin in chicks. Br. Poult. Sci., 56: 459-69.

Evans, R.J. 1988. Hepatobiliary damage and dysfunction. A critical review. In: Blackmore A.J (Ed), Animal Clinical Biochemistry, Cambridge.

Hosamani, S.V. 1992. Factors affecting the variations in urea molasses block intake and its utilization in buffaloes. Ph.D. Thesis, Deemed University, IVRI, Izatnagar, U.P., India.

Hossain, F.M.A., Hasnath, M.R. and Kabir, M.S. 2011. Hematobiochemical dynamics and body weight gain of Black Bengal goat following urea molasses block (UMB) supplementation. Online J. Anim. Feed Res., 1(5): 182-185.

Jain, N., Tiwari, S.P. and Singh, P. 2005. Effect of urea molasses mineral granules UMMG on rumen fermentation pattern and blood biochemical constituents in goat kids fed sola Aeschonomene indica Linn grass-based diet. Vet. Arch., 75(6): 521-530

Kaneko, J.J. 1980. Clinical Biochemistry of Domestic Animals. Academic Press Inc, Orlando, Florida.

Kaneko, J.J., Harvey, J.W. and Bruss, M.L. 2008. Clinical Biochemistry of Domestic Animals. $6^{\text {th }}$ ed. Academic Press, San Diego, USA.

Kerketta, N., Victor, V.M., Praveen, K. and Chandraker, A.K. 2019. Effect of urea treated rice straw along with urea molasses mineral block supplementation on body weight gain, feed intake and haemato-biochemical parameters of working bullocks. Int. J. Livest. Res., 9(7): 154-163.

Kumari, P., Singh, P., Verma, A.K., Gaur, G.K. and Das, A. 2020. Effect of molasses based multi-nutrient herbal supplements on in vitro digestibility, serum enzymes and minerals profile in buffalo calves. Indian J. Anim. Sci., 90(2): 201-206.

Kumar, S., Singh S.V., Pandey, P., Lone S. A. and Upadhyay, R.C. 2016. Effect of molasses feeding on biochemical and hormonal parameters in Sahiwal and Karan Fries heifers. $J$. Anim. Res., 6(6): 995-999.

Kunju, P.J.G. 1986. Urea molasses block: A future animal feed supplement. Asian Livest., 11: 154-157.

Lehninger, A.L., Nelson, D.L. and Cox, M.M. 1993. Principles of Biochemistry $2^{\text {nd }}$ edition CBS Publ. New Delhi.
Lohakare, J.D., Pattanaik, A.K. and Khan, S A. 2006. Effect of dietary protein levels on the performance, nutrient balances, metabolic profile and thyroid hormones of crossbred calves. Asian-Aust. J. Anim. Sci., 19: 1588-1596.

Mckenzie, R.A. 1991. Bentonite as therapy for lantana camera poisoning of cattle. Aust. Vet. J., 68: 146.

Mohini, M. and Gupta, B.N. 1993. Nutrient utilization in buffaloes fed paddy straw supplemented with UMMB. Indian J. Anim. Nutr., 10: 217-221.

Patil, A.K., Verma, A.K., Singh, P., Das, A. and Gaur, G.K. 2017. Effect of molasses based multinutrients and chromium supplementation on the haematological and blood biochemical profile in lactating murrah buffaloes. J. Anim. Res., 7(2): 1-9.

Petrie, L. 1987. Differential diagnosis of diarrhoea in adult cattle. Practice, 9: 50-57.

Phukan, M., Baruah, A., Sharma, B.C., Baruah, K.K. and Kalita, D.J. 2000. Serum macro and micro mineral levels in crossbred (Jersey $\times$ Assam local) calves during pre-weaning and post-weaning periods. Ind. Vet. J., 77: 583-585.

Prasad, C.S., Gowda, N.K. and Raman, J.V. 2001. Feeding strategies for enhance animal productivity. In: proceeding Xth Animal Nutrition Conference, NDRI, Karnal, India, pp. $23-45$.

Promkot, C. and Wanapat, M. 2005. Effect of level of crude protein and use of cottonseed meal in diets containing cassava chips and rice straw for lactating dairy cows. Asian-Aust. $J$. Anim. Sci., 18: 502-511.

Raman, R. S., Chahal, S. M. and Sihag, Z. S. 2010. Effects of supplementation of urea molasses mineral blocks on growth, nutrient utilization and blood metabolites in growing buffalo heifers. Indian J. Anim. Nutr., 27: 116-21.

Salem, F.A.F., El-Amary, H. and Hassanin, S.H. 2001. Effect of bentonite supplementation on nutrients digestibility, rumen fermentation, some blood physiological parameters and performance of growing lambs. Egyptian J. Nutr. Feeds, 4: 179-191.

Sihag, Z.S., Berwal, R.S., Sihag, S. and Nand Kishore. 2008. Effect of different feed ingredients on the hardness and chemical composition of lick blocks. Indian J. Anim. Nutr., 25 (1): 43-46.

Silanikove, N., Gilboa, N., Nitsan, Z. and Perevolotsky, A. 1996. Effect of daily supplementation of polyethylene glycol on intake and digestion of tannin containing leaves (Quercus calliprinos, Pistasia lenticus and Ceratonia siliqua) by goats. J. Agric. Food Chem., 44: 199-205. 
Snedecor, G. W. and Cochran, W. G. 1994. Statistical methods. $8^{\text {th }}$ Edn. Iowa State Univ., Iowa, USA.

Sun, S. and Christopherson, R.J. 2005. Urea kinetics in wethers exposed to different ambient temperatures at three dietary levels of crude protein. Asian-Aust. J. Anim. Sci., 18: 795801.
Tiwari, S.P. 1988. Studies on solidified urea molasses based block licks in buffalo calves fed low quality crop residuces. Ph.D. Thesis, IVRI, Izatnagar, U.P., India.

Tiwari, S.P., Angan, R., Samiran, M. and Gendley, M.K. 2010. Subchronic toxicity study of urea molasses mineral Block in goat kids. Egypt. J. Sheep Goat. Sci., 5(1): 323-333. 